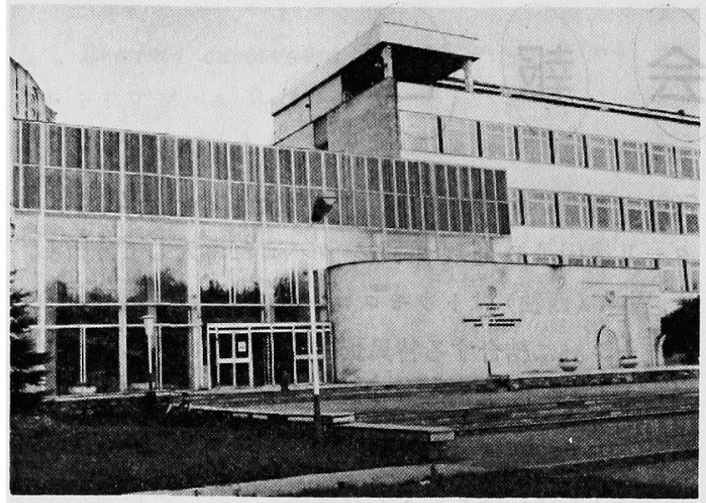

写真 1 シンポジウムの会場となった微生物生化学 生理学研究所の玄関

の発言はあまり多くなかった。また，2 日目の夕方はり 連の研究者によるポスターセッションがあった.

朝 8 時からの朝食から始まって夕食が終る 10 時ごろ をでかなりのハードなスケジュールであったが，人工の 町であるため見物するものもなくほぼ全員参加してのシ ンポジウムであったが, 組織委員を除いたソ連の研究者 之外国人は一番インフォーマルな情報交換のできる食事 時に別々にされてしまったのは枑いに残念であった （外国人には良い食事を出すためらしかった）。

組織委員の Skryabin 教授でさえ 1 年半前に研究グル ープの一つを植物分子生物学分野にしたいといっていた ように,この分野のソ連の研究は始むったばかりと思わ れる、会議の前後にモスクワのソ連科学アカデミ一の研 究所を見学する機会を与えられたが，モスクワに関する 限り最新の設備があり，スペースもゆったりしており清 潔でららやましい限りであった，ソ連では伝統的に生物

微生物における凝結晶性表層構造体

微生物の細胞最外層に存在する凝結晶性構造は S-layer と呼ばれている. EMBO の援助によって第 2 回 Slayer ワークショップがウィーンで 8 月 31 日がら 9 月 2 日まで開催された。第 1 回ワークショップが 3 年前に もたれたが今回もウィーン農業大学 Sleytr 教授によっ て開催された.

ワークショップは写真にあるよらに歴史の重みが感じ られる農業大学に新築された Franz-Schwockhöfer-haus

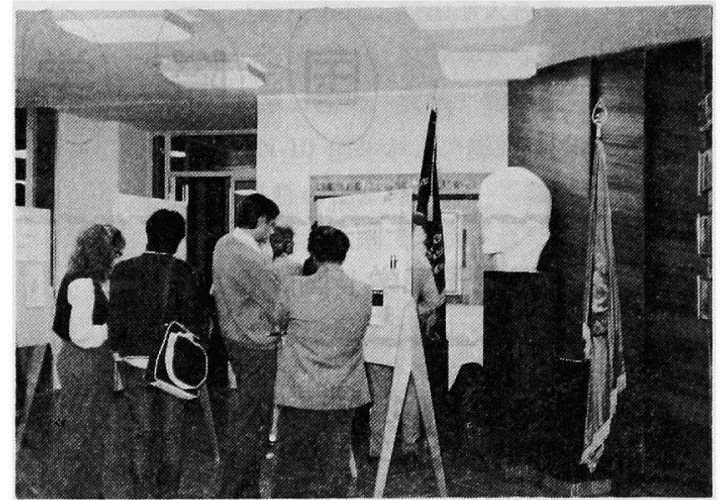

写真 2 レーニンの像も置かれているポスターセッ ションの会場

有機化学, タンパクと核酸の化学および物理化学の研究 ががっちりと重厚に行われてきており, 研究所間の連係 や共同研究も積極的に行ら方針とのことであった.

ソ連では, 研究所員はすべてパーマネントのポジショ ンであるが，その弊害を少なくするため 20 年間で全員 がローテーションする計画になっているとのことであ る. また，若い研究者をできるだけ外国で教育させてい るようで，とくにこの分野では東側で最も研究の進んで いるハンガリーとの交流が深いよらである. 実際、今回 のシンポジウムの参加者もハンガリーからは外国人 26 名中 5 名と最も多かった. また外国企業からの参加者も 5 名であった. ソ連ではこの会議を手始めに植物バイオ テクノロジー分野に本格的に取組んでいくことが予想さ れ，世界のこの分野の研究の発展に大いに寄与されるこ とと期待される.

\section{(名古屋大学遗伝子実験施設 杉浦昂弘)}

で開かれた，EMBO の援助を受けた関係かもしれない が, ヨーロッパ各国からの参加者が多く, ヨーロッパ以 外ではカナダ人と日本人として私一人の約 50 名の参加 者があった. 講演は午前 9 時〜12 時と午後 1 時〜 5 時 の間行われ，その間にポスターセッションも開かれ大変 盛り沢山であったまた夜は “Heuriger”といって, 今 年ウィーン郊外でできたワインを飲むことのできるレス トランで食事を一緒にし楽しい一時（といっても夜 12 時ごろまで）を過ごせる機会が 2 度もあった。

今年のヨーロッパは異常気象に見舞われ，雨が多く寒 い夏であったが, ワークショップが開催されるころより 天候が例年並みに戻り， Sleytr 教授の最初の挨拶は「皆 
さんがウィーンに良い天候を持ってきて下さいました」」 から始まった. Sleytr 教授は S-layer の応用研究を強調 され，今回は後半に応用面の開発といら講演も予定され 次の 4つのカテゴリーで講演発表がなされた１）S-layer の化学的性質, 2) S-layer の構造, 3) S-layer の遗 伝子，4）S-layer の応用.

古細菌を含む陰性菌やグラム陽性菌の S-layer は多 くの場合蛋白質（分子量 4 20 万）で構成されている が, Halobacterium halobium (J. Lechner) と Bacillus stearothermophilus (P. Messner and U. B. Sleytr) の S-layer は糖蛋白質で構成されている. 後述するように H. halobium の S-layer 蛋白質の遺伝子はクローン化さ れ塩基配列も決定されている. M. Kessel は H. halobium の S-layer 構造に関する三次元的解析結果と塩基 配列から類推されるアミノ酸配列を比較し，C末端側が 細胞質膜中に埋め込まれ，スペーサー領域があり $\mathrm{N}$ 末端 側が細胞最外層に結晶構造を形成するモデルを提出して いた. またスペーサー領域には糖鎖の修飾部位が cluster をなして存在していることも化学的に明らか炕され た (J. Lechner). アミノ酸配列と立体棈造とがまだ完全 に一致させることができていないが，構造とアミノ酸配 列の関係では S-layer 構造中一番進んでいると思われ た. W. Baumeister のグループは細菌表層構造体の進化 という点に興味を抱き，古細菌を中心としたいろいろな 細菌上の S-layer 構造の三次元的解析に成功している.

I. Wildhaber は Sulfolobales 嘱する好熱性古細菌 Thermoproteus tenax 打よび Desulfurococcus mobilis のS-layer 三次構造を発表した. 両者とも六角格子状を 二次元的に示すが，三次元的には外側が smooth で内側 が rough な状態を示していた. しかし両 S-layer の蛋白 質は非常にタフでどんな溶凬でも可溶化することができ ず，蛋白質の性質を明らかにすることができていないの が残念であった，古細菌とはペプチドグリカン層が存在 しないのでここれら非常にタフな蛋白質で構成される S-layer が細胞の形を決定し䧽持しているのではないか と考兄ている. 一方, W. Baumeister はSulfolobus属細菌 についてその S-layer 三次構造を比較した発表を行った. 細胞質膜に近い汪う（内側）の構造は非常に類似してい るのに対して，外界と接している面 (外側) は巽なって おり，進化の過程で外界の影響の受け方が異なった結果 であろらと考えている.カナダのグループでは R. G.E. Murray は以前より Aquasperium serpens の S-layer に

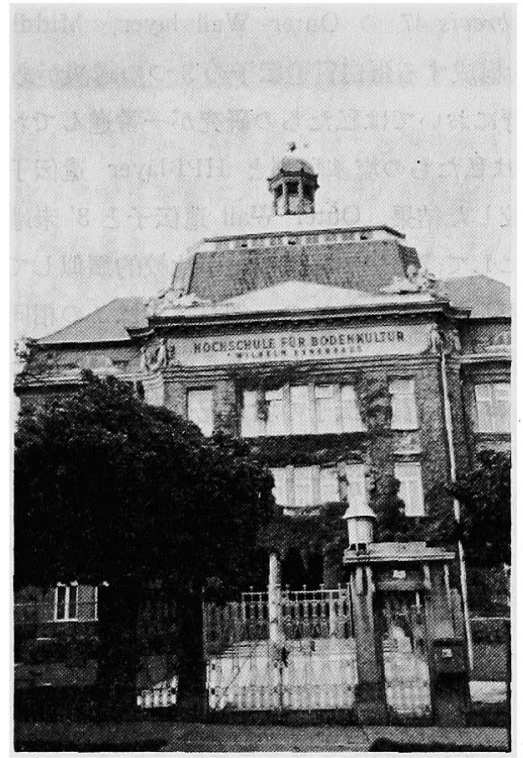

写真 1860 年代に建築されたウィーン農業大学の 正面の写真. 当日は日曜日で正門は完全に鍵 がかかって拈り，誰も人がいなかった。

ついて研究しているが，今回はS.F. Koval が S-layer を構成する蛋白質が $125 \mathrm{~K}$ と $150 \mathrm{~K}$ の 2 種類でそれぞ れが S-layer を構成するだららと発表したが，蛋白質化 学的な解析もこれからだと感じた。また， T. J. Beveridge，T.J. Trust 等はサケの病原菌である Aeromonas salmonicida の S-layer Aeromonas のA を使って A-layer と呼び，その構造拈よび生理的意義について発 表した.A-layer は四角格子状の結晶構造を示し分子量 $49 \mathrm{~K}$ の蛋白質から構成されている. A-layer を欠いた変 異株は毒性が $10^{5}$ のオーダーで低下することより Alayer は血清の殺菌作用から保護する働きがあると考学 ており，表層構造体の生理活性を研究する良い材料とな ろうと強調していた． T. J. Trust は A-layer 蛋白質遺伝 子のクローニングを試みているが，なかなか $5^{\prime}$ 側の遺 伝子をクローン化できないとも述べていた．これはわれ われが研究している B. brevis 47 の場合も同様であり， 細胞中に大量に存在する蛋白質遺伝子のクローン化のむ ずかしさといら点で意見が一致した。

S-layer 構成蛋白質の遺伝子に関しては先に記したJ. Lechner による H. halobium の糖蛋白質遗伝子, W. Baumeister のグループから J. Peters による Deinococcus radiodurans $\sigma$ Hexagonally packed intermediate layer（HPI-layer）を構成する蛋白質遺伝子そして私た 
bの B.brevis 47 ○ Outer Wall layer, Middle Wall

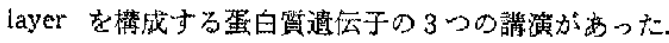
この分野火和いては私たらの研究が一番進んで和り，J.

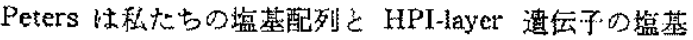
列老比較した結果，Outer Wall 造后子と $3^{\prime}$ 未端側でフ ミノ酸にして76アミノ酸牫基が比较的類似しているこ とを発表した。しかしこの一例だけではこの相问領域が どんな意味がある台結論つけすことはできずさら多く の S-layer 蛋白質遗伝子の塩基配列が決定されることが 望扎た。私は B. brevis 47 の S-layer 蛋白質遗伝子の

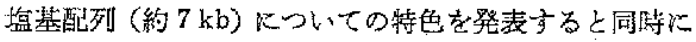
S-layer 遗伝子上のブロモーター，シグオルペブチド配

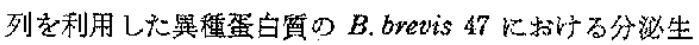
産について講演 L, Sleytr 教授の今回のワークショッ

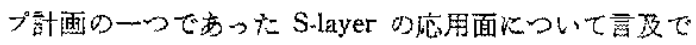
き Sleytr 新授を满足させることができた。

最後のセッションは私が同会を行い, Sleytr教援がこ こ数年研究されている S-layer 構造体を利用寸る講演が M. Sara および C. Manigley kよってなされた.

B. stearothermophilus k約 $4 \mathrm{~nm}$ の穴を有年る Slayer，が存在することに注目して，4 nm の穴を利用した

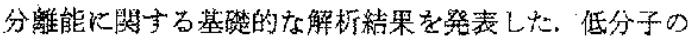
mannose 蛋白質です myoglobin (17.9K), carbonic

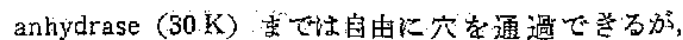
ovalbumin (43 K) 以上の大蟫白筫比なるるとん ど通過できないことを示 $\mathrm{L} ， 40 \mathrm{~K}$ 前後の蛋白質を分離 でること老眀らがした. しかしクロートグラフィー

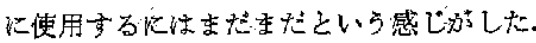

請㴼会後，R.G.E.Murray 教授（莱年停年退職の予 定)に上节司会て今後どのように S-layer 研究を発展さ せるべきかついて総合討論会が開かれた。第1回の S-layer ワークショップで S-layer の立体構造解析, 蛋

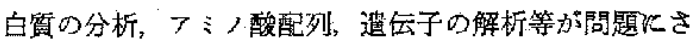
れたが，今回これらの面で著しい進热が方った、今後は S-layer の生理的な意義ならびそての生会成過屋をさら

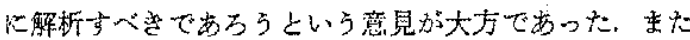
S-layer の定義化ついて子議論し，最近Sleytr 教授より

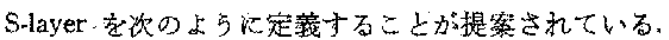

"Surface envelope components on prokaryotic cells consisting of two-dimensional crystalline arrays of proteinaceous subunits"

最後になり史したか゚，(財)费䒧化学的究奖励会より口 ークショップ参加莹用を援助していただき，新しい多? の知人を得る機会を得まして心より感櫭いたしをす。

(名㟔厤大学農学部 塚越規弘) 